\title{
Analytical Procedures for Evaluating the Raw Material Component of Sugar Production
}

\author{
Nuzhdin R.V.* \\ Department of Theory of Economics and Accounting Policy \\ Voronezh State University of Engineering Technologies \\ Voronezh, Russia \\ e-mail: rv.voronezh@gmail.com

\section{Kondrashova N.V.} \\ Department of Economic Analysis and Audit \\ Voronezh State University \\ Voronezh, Russia \\ e-mail: n.kondrashova@outlook.com
}

\author{
Maslova I.N. \\ Department of f Finance and Credit \\ Voronezh state agrarian university \\ Voronezh, Russia \\ e-mail: irimslv@mail.ru
}

\author{
Panina Ye.B. \\ Department of Economic Analysis, Statistics and Applied \\ Mathematics \\ Voronezh state agrarian university \\ Voronezh, Russia \\ e-mail: yelena.panina2014@yandex.ru
}

\begin{abstract}
Traditional analytical tools are worked out in sufficient detail at a theoretical level and are methodologically formalized. However, the indicators used in practice do not have systemic unity and only fragmentarily take into account the features of economic activity. For the development of effective analytical tools of assess the raw material component, a system of five key indicators is proposed. The system includes two traditional indicators and three new ones. The formation of the final synthetic indicator is provided by ranking and rating the values of indicators object-wise, in space, in time and in general for organizations for the analyzed period. Testing of analytical procedures was carried out based on the materials of eight organizations of sugar production in the Voronezh region for the period 2012-2018, which allowed identifying a certain lack of attention to the process from the management of organizations and to conclude that a systematic approach is needed not only to form key indicators, but also to rating organizations, that is, to build ratings based on the evaluation of all components of economic activity, which will increase the objectivity of analytical conclusions.
\end{abstract}

Keywords - sugar production; resource potential; raw material component; key indicators; analytical procedures; ranking and rating.

\section{INTRODUCTION}

The economic activity of production organizations is associated with the constant search and implementation of innovative opportunities for the development of resource potential and the appropriate use of its components - technical, raw materials and labor. If the first component is associated with non-mobile assets, the raw and labor components, characterized by a greater degree of mobility, are able to more intensively influence the processes of increasing and optimizing the value of the business, which, of course, affects the interests of many stakeholders. For material-intensive industries, including sugar production, the development of the raw material component of the resource potential is of the greatest importance for the growth of value added.

The magnitude of the mobile activity of a raw material component with a different impact vector is influenced by many factors of the business environment in which economic activity is carried out. This influence is manifested in the form of a variety of indicators as the results of using the resource potential of production organizations. As a rule, at the methodological level they are sufficiently formalized, but their practical application is limited in a certain way. Firstly because they do not take into account or underestimate the specific features of the business, which is evaluated with their help. Secondly, they have a limited standard set of indicators, despite the loss by some of them of their analytical capabilities due to significantly changed conditions for organizing the resource potential. Thirdly, the evaluation methodological procedures themselves, as a rule, rely on a set of well-known indicators that make it difficult to draw objective conclusions, and not on a system of key indicators that allows proactive approaches to be used in assessment (in particular, rating) and, on this basis, improve accuracy the reliability of judgments. However, there is a particular dependence between the processes of analysis and evaluation related to their applicability to such an object of economic activity as the resource potential, since they cannot be identified (which is very common in practical applications), but they cannot be separated (which can also be observe in research work). Meanwhile, an assessment as conclusions of different levels is required to complete any analytical activity, which consists in finding the causes and consequences of factors, situations, events, phenomena described in relation to such a manager tool, as an indicator, first formal (mathematical), and then numeric language. Therefore, an inevitable need arises for a constant update or search for new analytical tools (key indicators) for their assessment.

In this work, the goal is to substantiate the system of key indicators of the raw material component of the economic activity of sugar production organizations, eliminating the drawbacks of the existing indicative complexes, to develop and test a methodology for assessing the raw material component based on phased rating, which allows, in contrast to existing approaches, to evaluate the results of using mobile resource potential objectwise, in space, in time and in general for organizations for the analyzed period, as well as to give the authors' vision of the 
nature and content of the analytical procedures and the indicators, both traditional and offered for the first time, to enhance the level of their suitability for analytical use by managers as estimative economical instruments.

\section{METHODS AND MATERIALS}

The analysis as an independent area of economic research is an attributive process of Russian management. We can assume that from a methodological point of view, modern economic science pays enough attention to the methods and logic of conducting analytical procedures that determine the very essence of the analysis methodology. However, the modern view of Russian scientists about the role of the latter is rather different $[9,12]$. It should be noted the timeliness and unconditional importance of ideas for the development of methods and tools of economic analysis, which were introduced by A.D. Sheremet [2, 3], V.V. Kovalev [16], D.A. Endovitsky and N.P. Lyubushin [5], G.V. Savitskaya $[6,7]$, V.I. Barilenko [14] and others. To one degree or another, these scientists made a certain contribution to the evolution of economic analysis and disclosed its role in the system of organization management processes.

A special contribution to determining the advantages of economic analysis and its significance for the competitive development of domestic organizations belongs to M.V. Melnik. She noted the features of modern economic analysis, which must be taken into account when substantiating the methodology and choosing analytical tools:

- the use of a reproductive approach appropriate to the current economic environment [8];

- the systematic approach strengthening, which is manifested in a certain hierarchy and focus, and implemented in the form of concepts: key indicators, the main factors affecting them and the synergy of the effect of indicators on the final results of the enterprise [8];

- the implementation of a process approach for continuous information and analytical support for management, linking the subject of analysis with business processes and giving the opportunity to link the processes of movement of material and material resources and money [8].

Thus, the purpose of evaluating the raw material component of the economic activity of sugar production organizations is:

- $\quad$ selection of objects and periods for analysis;

- selection and justification of key indicators;

- calculation and analysis of key indicators;

- selection and justification of the methodology for assessing key indicators (rating).

The greatest diligence and responsibility should be applied when choosing key indicators, so that their information content is consistent with the goal. Therefore, the selection of key indicators for our analysis was carried out taking into account such aspects as: the influence of factors of the business environment (direct and indirect); the principle of coverage of the main business processes; the systemic relationships of indicators corresponding to a specific component of the resource potential of the organization as a system. Table 1 summarizes the systems of key indicators of raw material component assessment that we see as suitable for rating. The proposed system of key indicators contains two groups: two indicators $\left(\mathrm{K}_{1}\right.$ and $\left.\mathrm{K}_{2}\right)$ are traditional for sugar production organizations; and three indicators $\left(\mathrm{K}_{3}, \mathrm{~K}_{4}, \mathrm{~K}_{5}\right)$ are proposed for the first time.

TABLE I. THE SYSTEM OF KEY INDICATORS OF THE RAW MATERIAL COMPONENT OF THE ECONOMIC ACTIVITY OF SUGAR PRODUCTION

\begin{tabular}{|c|c|c|}
\hline Index & $\begin{array}{c}\text { Calculation } \\
\text { formula }\end{array}$ & Meaning and essence \\
\hline $\begin{array}{l}\text { The } \\
\text { coefficient } \\
\text { of sugar } \\
\text { extraction } \\
\text { from beets, } \\
\text { unit }\left(\mathrm{K}_{1}\right)\end{array}$ & $\begin{array}{l}\mathrm{K}_{1}=\mathrm{Y} / \mathrm{S} * 100, \\
\text { where } \\
\mathrm{Y} \text { - sugar yield, } \\
\% \\
\mathrm{~S} \text { - beet digestion } \\
\text { when harvested, \% }\end{array}$ & $\begin{array}{l}\text { It characterizes the quality of the } \\
\text { process of extracting sugar from } \\
\text { harvested beets. } \\
\text { It shows how much sugar contained in } \\
\text { the harvested beets was obtained as a } \\
\text { result of its processing, taking into } \\
\text { account the loss of sugar during } \\
\text { storage and production. }\end{array}$ \\
\hline $\begin{array}{l}\text { The share of } \\
\text { material costs } \\
\text { in total costs, } \\
\text { percent }\left(\mathrm{K}_{2}\right)\end{array}$ & $\begin{array}{l}\mathrm{K}_{2}=\mathrm{MC} / \mathrm{TC}, \\
\text { where } \\
\mathrm{MC} \text { - material } \\
\text { costs, rubles } \\
\mathrm{TC} \text { - total costs, } \\
\text { rubles }\end{array}$ & $\begin{array}{l}\text { It characterizes the role of the raw } \\
\text { material component in the formation } \\
\text { of expenses for production activities. } \\
\text { Shows how much of the total costs } \\
\text { account for raw materials. }\end{array}$ \\
\hline $\begin{array}{l}\text { Payback of } \\
\text { materials, } \\
\text { rubles per } \\
\text { ruble }\left(\mathrm{K}_{3}\right)\end{array}$ & $\begin{array}{l}\mathrm{K}_{3}=\mathrm{VA} / \mathrm{MC}, \\
\text { where } \\
\mathrm{VA}-\text { value } \\
\text { added, rubles }\end{array}$ & $\begin{array}{l}\text { It characterizes the role of internal } \\
\text { consumption of material resources in } \\
\text { the process of adding value. } \\
\text { Shows how much added value is } \\
\text { accounted for each ruble of consumed } \\
\text { material resources. }\end{array}$ \\
\hline $\begin{array}{l}\text { Material } \\
\text { consumption, } \\
\text { rubles per } \\
\text { ruble }\left(\mathrm{K}_{4}\right)\end{array}$ & $\begin{array}{l}\mathrm{K}_{4}=\mathrm{MC} / \mathrm{TS}, \\
\text { where } \\
\mathrm{TS} \text { - total sales }\end{array}$ & $\begin{array}{l}\text { It characterizes the role of raw } \\
\text { materials in the process of sales value } \\
\text { formation. } \\
\text { Shows how much material costs per } \\
\text { ruble of manufactured products. }\end{array}$ \\
\hline $\begin{array}{l}\text { Resource } \\
\text { compliance } \\
\text { ratio (for } \\
\text { material } \\
\text { costs), rubles } \\
\text { per ruble }\left(\mathrm{K}_{5}\right) \\
\end{array}$ & $\begin{array}{l}\mathrm{K}_{5}= \\
\text { where } \\
\mathrm{FA}-\text { value of } \\
\text { fixed assets, } \\
\text { rubles }\end{array}$ & $\begin{array}{l}\text { It characterizes the role of the raw } \\
\text { material and technical component of } \\
\text { the main production. } \\
\text { Shows the amount of material costs } \\
\text { per ruble of fixed assets. }\end{array}$ \\
\hline
\end{tabular}

Rating itself, which is becoming more widespread in management as a universal assessment process, can be carried out by various methodological tools, but its results are always signal information for making appropriate management decisions to mobilize the identified opportunities for optimizing the raw materials component of production organizations

Among the methodological approaches to the determination of an integral indicator that have been recognized in domestic analytical practice, it is necessary to distinguish the "sum of places" methodology. According to this methodology ranking is performed by calculating the total number of places assigned to each indicator depending on its minimum or maximum level $[1,17]$. 
Methodological assessment procedures based on rating should be carried out in stages in accordance with a certain algorithm, the hierarchy of which is as follows:

- ranking of key indicators for each organization by year;

- ranking organizations for each indicator by year;

- determination of the integral rating of the organization on average for the entire period.

This methodological assessment approach eliminates the existing drawbacks of the traditional rating method, when ratings are set only for organizations for a period, and indicators for organizations are not ranked.

The processes of functioning and development of domestic production organizations in the agro-industrial complex show that the most vulnerable side of management is an excessive concentration of attention on the technological side of production, while the material and raw materials component of the resource potential in achieving the necessary profitability and ensuring competitive stability are underestimated.

To estimate the level of realization of the potential of the organization's resources, it is necessary not only to apply analytical indicators covering all aspects of economic activity, but also to select appropriate tools from the accumulated analytical practice, as well as to update them or create new ones that have no analogues, but which contribute to strengthening the objectivity of evaluative conclusions. Traditionally, analysts use as a tool (simple and informationally accessible "analytical units") a set of indicators such as: natural, labor, cost, absolute and relative. The configurations of relative indicators are well known and are considered preferable for analytical procedures $[4,10,12$, 13]. However, the ratios of cost indicators with natural indicators that implement the economic approach in studies related to rating are still insufficiently applied. In addition, as we have already noted [11], from the methodological point of view, the procedures for establishing ratings have significant drawbacks - suboptimal validity or lack of key indicators, underestimation of systematicity in their selection, use of outdated and uninformative formulas, narrowly focused procedural presentation that does not recognize the priority of the mobile component of the resource potential of the business.

At present, rating is becoming more common tool to identify the most successful organizations. In particular, Russian sugar factories are ranked annually in accordance with the Regulation on the competition "The Best Sugar Factory in Russia", which is held by the Union of Sugar Producers of Russia Non-Profit Organization Soyuzrossahar together with the Ministry of Agriculture of the Russian Federation. When determining the best sugar factories, the following key indicators are taken into account: average daily productivity; the coefficient of sugar extraction from beets in the second half of the year; sugar content in molasses; specific fuel consumption; specific consumption of limestone; production of dried (granulated) pulp; extra white sugar production; creation of new types of production.
We believe that the described methodological approaches cannot show the full results of the achievements of sugar production organizations, since they use either natural indicators or relative indicators that compare only natural ones, and such an indicator as sugar beet digestion is not an achievement of sugar factories at all. As can be seen from the above facts, the rating process completely ignores social and economic indicators, which can lead to a significant distortion of the rating results as management evaluation tools.

\section{RESULTS}

In a detailed form, analytical procedures and rating are proposed to be carried out as follows:

the values of key indicators of the raw material component of the economic activity of organizations are determined;

by the method of "sum of places" key indicators are separately ranked according to the criterion "best place $=$ min" for each organization for each year of evaluation according to the principle: indicator rating - its place number;

by the method of "sum of places" all key indicators for each organization for a seven-year period are ranked according to the principle: dynamic rating of the year - its place number;

the method of "sum of places" determines the integrated rating of the raw material component of the economic activity of organizations on average over a seven-year period on the basis of the weighted average key indicators.

We selected 8 sugar production organizations of the Voronezh region that have similar characteristics as objects of study: they are part of the Prodimeks group of companies, are managed by PRODIMEX - SUGAR LLC, and they produce products from the same raw materials - sugar beets; have comparable ratios between the number of categories of personnel, as well as other technical and technological parameters. The study period is 2012-2018, which provides a high level of reliability of analytical results and objectivity of rating.

At the first stage, the values of key indicators of the raw material component of the economic activity of 8 organizations of the Voronezh region (coded C1-C8) for 2012-2018 were calculated (Table 2).

It should be noted that the smallest range of variation was observed on traditional indicators $\left(\mathrm{K}_{1}\right.$ and $\left.\mathrm{K}_{2}\right)$, which is explained by their specific focus. The values of the remaining indicators varied in a rather wide range, both by organization and by year.

The value of the coefficient of sugar extraction (K1) in 47 of 56 cases (83.93\% of all observations) ranged from 0.8 to 0.9 units. The main factor that has the greatest impact on the level of this indicator (with a practically unchanged level of technology and organization of production in the period under review) is sugar beet digestion when it comes to the sugar factory. In most cases, the directions of the dynamics of the sugar extraction coefficient are co-directed by organizations, due to the territorial proximity to the location of the raw material bases of sugar factories and similar climatic conditions. 

ORGANIZATIONS C1 - C8 OF THE VORONEZH REGION (2012-2018)

\begin{tabular}{|c|c|c|c|c|c|c|c|c|c|}
\hline \multirow{2}{*}{ Indexes } & \multirow{2}{*}{ Year } & \multicolumn{8}{|c|}{ Organization } \\
\hline & & C1 & $\mathrm{C2}$ & $\mathrm{C3}$ & $\mathrm{C4}$ & $\mathrm{C5}$ & C6 & C7 & C8 \\
\hline \multirow{7}{*}{$\begin{array}{l}\text { The coefficient of sugar } \\
\text { extraction from beets }\end{array}$} & 2012 & 0.8253 & 0.7943 & 0.7905 & 0.8011 & 0.8496 & 0.7832 & 0.8480 & 0.8210 \\
\hline & 2013 & 0.8167 & 0.7943 & 0.7709 & 0.8248 & 0.8420 & 0.7712 & 0.8479 & 0.8117 \\
\hline & 2014 & 0.8939 & 0.8614 & 0.9024 & 0.8706 & 0.8514 & 0.8587 & 0.9120 & 0.8751 \\
\hline & 2015 & 0.8800 & 0.9001 & 0.8797 & 0.8930 & 0.8801 & 0.8381 & 0.8944 & 0.8778 \\
\hline & 2016 & 0.8709 & 0.8787 & 0.8908 & 0.8829 & 0.8460 & 0.8218 & 0.8560 & 0.8758 \\
\hline & 2017 & 0.8489 & 0.8652 & 0.8923 & 0.8785 & 0.8233 & 0.8301 & 0.8809 & 0.8667 \\
\hline & 2018 & 0.8576 & 0.8527 & 0.8995 & 0.8456 & 0.8847 & 0.8731 & 0.8927 & 0.8720 \\
\hline \multirow{7}{*}{$\begin{array}{l}\text { The share of material costs } \\
\text { in total costs, percent }\end{array}$} & 2012 & 76.40 & 76.20 & 84.87 & 69.66 & 77.93 & 79.35 & 75.85 & 73.92 \\
\hline & 2013 & 75.64 & 76.02 & 90.64 & 63.07 & 76.72 & 57.14 & 81.25 & 58.96 \\
\hline & 2014 & 75.82 & 53.25 & 87.55 & 74.87 & 73.55 & 65.82 & 77.70 & 65.65 \\
\hline & 2015 & 84.78 & 76.24 & 87.89 & 75.09 & 83.51 & 82.63 & 81.93 & 80.24 \\
\hline & 2016 & 87.02 & 82.14 & 81.20 & 79.93 & 81.46 & 84.87 & 83.43 & 84.10 \\
\hline & 2017 & 86.47 & 78.78 & 83.43 & 79.73 & 75.07 & 78.78 & 83.01 & 66.97 \\
\hline & 2018 & 83.26 & 78.28 & 77.22 & 84.86 & 58.49 & 79.02 & 76.77 & 74.21 \\
\hline \multirow{7}{*}{$\begin{array}{l}\text { Payback of materials, } \\
\text { rubles per ruble }\end{array}$} & 2012 & 0.381 & 0.383 & 0.377 & 0.404 & 0.430 & 0.372 & 0.388 & 0.321 \\
\hline & 2013 & 0.387 & 0.340 & 0.382 & 0.341 & 0.424 & 0.298 & 0.508 & 0.409 \\
\hline & 2014 & 0.686 & 0.760 & 0.535 & 0.963 & 0.561 & 0.809 & 0.546 & 0.613 \\
\hline & 2015 & 1.091 & 1.225 & 0.708 & 0.943 & 0.971 & 0.715 & 1.209 & 1.144 \\
\hline & 2016 & 0.902 & 1.064 & 0.859 & 0.799 & 0.718 & 0.558 & 0.914 & 0.866 \\
\hline & 2017 & 0.503 & 0.482 & 0.491 & 0.390 & 0.337 & 0.291 & 0.439 & 0.427 \\
\hline & 2018 & 0.532 & 0.652 & 0.691 & 0.396 & 1.076 & 0.458 & 0.821 & 0.846 \\
\hline \multirow{7}{*}{$\begin{array}{l}\text { Material consumption, } \\
\text { rubles per ruble }\end{array}$} & 2012 & 0.724 & 0.723 & 0.726 & 0.712 & 0.699 & 0.729 & 0.721 & 0.757 \\
\hline & 2013 & 0.721 & 0.746 & 0.724 & 0.746 & 0.702 & 0.770 & 0.663 & 0.710 \\
\hline & 2014 & 0.593 & 0.568 & 0.652 & 0.510 & 0.641 & 0.553 & 0.647 & 0.620 \\
\hline & 2015 & 0.478 & 0.450 & 0.586 & 0.515 & 0.507 & 0.583 & 0.453 & 0.466 \\
\hline & 2016 & 0.526 & 0.485 & 0.538 & 0.556 & 0.582 & 0.642 & 0.523 & 0.536 \\
\hline & 2017 & 0.665 & 0.675 & 0.671 & 0.720 & 0.748 & 0.774 & 0.695 & 0.701 \\
\hline & 2018 & 0.653 & 0.605 & 0.591 & 0.716 & 0.482 & 0.686 & 0.549 & 0.542 \\
\hline \multirow{7}{*}{$\begin{array}{l}\text { Resource compliance ratio } \\
\text { (for material costs), rubles } \\
\text { per ruble }\end{array}$} & 2012 & 2.19 & 1.77 & 4.87 & 1.63 & 2.83 & 14.00 & 12.32 & 4.15 \\
\hline & 2013 & 1.99 & 1.45 & 6.30 & 1.33 & 2.29 & 11.36 & 7.98 & 3.28 \\
\hline & 2014 & 1.33 & 0.94 & 6.55 & 1.18 & 1.92 & 8.17 & 6.98 & 2.97 \\
\hline & 2015 & 1.82 & 2.19 & 6.67 & 1.29 & 2.73 & 15.96 & 8.13 & 4.13 \\
\hline & 2016 & 2.31 & 3.37 & 4.60 & 2.30 & 1.29 & 32.82 & 9.38 & 6.52 \\
\hline & 2017 & 2.78 & 4.06 & 7.18 & 3.10 & 1.00 & 29.86 & 4.38 & 6.26 \\
\hline & 2018 & 2.55 & 4.25 & 5.08 & 2.79 & 0.42 & 22.88 & 1.97 & 2.65 \\
\hline
\end{tabular}

The share of material costs in total costs varies from 75 to $90 \%$ in 42 cases (75\% of all observations), while the level of the indicator is not significantly affected by the growth and / or decrease in the volume of processed raw materials, despite the high material consumption of sugar production.

The level of payback of materials (value added) ranged from 0.291 to 1.225 rubles per ruble. Material consumption ranged from 0.450 to 0.770 rubles per ruble. The multidirectional dynamics vector of these indicators is explained by heterogeneous comparison bases: in the first case, added value, in the second, the cost of sales, which, in turn, are subject to the different effects of material costs.

A significant range of variations, noted by the resource compliance ratio (for material costs) from 0.423 to 32.82 rubles per ruble, indicates, firstly, a different level of technical equipment and production capacity, including those expressed in the cost of fixed assets, secondly, about certain differences that are inherent in the process of adding value; thirdly, about prioritizing the development of individual organizations that are part of a group of companies. For example, the maximum values of this key indicator, incommensurably higher than the average values for a group of organizations, were obtained by organization C6, in which fixed assets were not updated. As a result, the value of these assets at the end of 2016 is 7 times less than that of C8 and 65 times less than that of C4. In 2019, the C6 organization was liquidated.

At the second stage, the key indicators for each organization for each year of the assessment according to the criterion of "best place $=$ min" are ranked by the "sum of places" method. Since the evaluation analysis period was 7 years, the "best place" was assigned to the best indicator, etc. as its level worsens. The best indicators $\mathrm{K}_{2}$ and $\mathrm{K}_{4}$ were considered to have the lowest arithmetic value due to their meaning, the best indicators $\mathrm{K}_{1}, \mathrm{~K}_{3}, \mathrm{~K}_{5}$ were considered to have the highest arithmetic value for the same reason; Further, the ranking was carried out respectively in the first group of indicators in ascending order, in the second - in decreasing the arithmetic value of the indicator. Since these calculations are intermediate, information on them is not given.

The third stage. For a reasonable judgment on the state of the raw material component of the economic activity of the organizations under study, the total amount of seats was calculated for all key indicators for a specific period (based on the data of the previous evaluation stage) and they were dynamically rated for each organization (table 3 ). 
TABLE III. DYNAMIC RATINGS OF THE RAW MATERIAL COMPONENT OF THE ECONOMIC ACTIVITY OF SUGAR PRODUCTION ORGANIZATIONS C1 - C8 OF THE VORONEZH REGION (2012 - 2018), PLACE

\begin{tabular}{|c|c|c|c|c|c|c|c|c|c|}
\hline \multirow{2}{*}{ Indexes } & \multirow{2}{*}{ Year } & \multicolumn{8}{|c|}{ Organization } \\
\hline & & C1 & $\mathrm{C2}$ & $\mathrm{C3}$ & $\mathrm{C4}$ & C5 & C6 & C7 & $\mathrm{C8}$ \\
\hline \multirow{7}{*}{$\begin{array}{l}\text { Sum } \\
\text { places, } \\
\text { number }\end{array}$} & 2012 & 29 & 28 & 30 & 25 & 18 & 24 & 28 & 27 \\
\hline & 2013 & 31 & 32 & 24 & 32 & 25 & 32 & 25 & 31 \\
\hline & 2014 & 20 & 24 & 15 & 18 & 21 & 17 & 19 & 23 \\
\hline & 2015 & 13 & 11 & 13 & 15 & 9 & 13 & 10 & 9 \\
\hline & 2016 & 11 & 10 & 19 & 13 & 18 & 13 & 12 & 8 \\
\hline & 2017 & 18 & 17 & 19 & 19 & 32 & 25 & 24 & 22 \\
\hline & 2018 & 18 & 17 & 20 & 18 & 17 & 16 & 22 & 20 \\
\hline \multirow{7}{*}{$\begin{array}{l}\text { The rating of } \\
\text { the year, place }\end{array}$} & 2012 & 6 & 6 & 7 & 6 & 3 & 5 & 7 & 6 \\
\hline & 2013 & 7 & 7 & 6 & 7 & 6 & 7 & 6 & 7 \\
\hline & 2014 & 5 & 5 & 2 & 3 & 5 & 4 & 3 & 5 \\
\hline & 2015 & 2 & 2 & 1 & 2 & 1 & 1 & 1 & 2 \\
\hline & 2016 & 1 & 1 & 3 & 1 & 3 & 1 & 2 & 1 \\
\hline & 2017 & 3 & 3 & 3 & 5 & 7 & 6 & 5 & 4 \\
\hline & 2018 & 3 & 3 & 5 & 3 & 2 & 3 & 4 & 3 \\
\hline
\end{tabular}

The results obtained give reason to draw the following conclusions:

- in organizations, an absolutely proactive vector of the dynamics of the development of economic activity was not noted (there was no annual improvement in the state of the raw material component);

- the optimistic development scenario corresponded to vectors of the dynamics of the level of the raw material component in organizations in the period 2012-2016;

- for the majority of organizations, the years 2015-2016 turned out to be the most stable from the standpoint of the development of the raw material component, and 2012-2013 were unstable.

It should be noted that such conclusions do not take into account the level of key indicators themselves, since the same amount of places scored by different organizations varies in level and content due to the ranking of key indicators of each organization independently of the other. However, such a procedure allows determining the trend of the dynamics vector or to reveal a lack of attention to the raw material component of economic activity.

At the fourth stage, the method of "sum of places" made an integrated rating assessment of the raw material component of the economic activity of the organization on average for the study period. Integral ratings were determined on the basis of the weighted average number of places in general over a seven-year period for all key indicators; further, organizations were ranked on average for all key indicators from 1st to 8th place. The calculation results are shown in table 4 .

Basically, for each year of a seven-year period, the C7 organization occupied the best places, the C6 organization had the worst place. The line of the integrated rating is structured as follows: organizations $\mathrm{C} 7, \mathrm{C} 8, \mathrm{C} 2, \mathrm{C} 5$ took the first four places, organizations $\mathrm{C} 3, \mathrm{C} 4, \mathrm{C} 1, \mathrm{C} 6$ shared the rest - the worst in rank. The materials in Fig. 1 clearly demonstrate the validity of such rating results in terms of deviations of key indicators of organizations from their place in the integrated rating.
TABLE IV. INTEGRAL RATING ASSESSMENT OF KEY INDICATORS OF THE RAW MATERIAL COMPONENT OF THE ECONOMIC ACTIVITY OF SUGAR PRODUCTION ORGANIZATIONS C1 - C8 OF THE VORONEZH REGION (2012-2018), PLACE

\begin{tabular}{|c|c|c|c|c|c|c|c|c|c|}
\hline \multirow{2}{*}{ Indexes } & \multirow{2}{*}{ Year } & \multicolumn{8}{|c|}{ Organization } \\
\hline & & C1 & C2 & C3 & $\mathrm{C4}$ & C5 & C6 & C7 & $\mathrm{C8}$ \\
\hline \multirow{7}{*}{$\begin{array}{l}\text { The coefficient } \\
\text { of sugar } \\
\text { extraction from } \\
\text { beets }\end{array}$} & 2012 & 3 & 6 & 7 & 5 & 1 & 8 & 2 & 4 \\
\hline & 2013 & 4 & 6 & 8 & 3 & 2 & 7 & 1 & 5 \\
\hline & 2014 & 3 & 6 & 2 & 5 & 8 & 7 & 1 & 4 \\
\hline & 2015 & 5 & 1 & 6 & 3 & 4 & 8 & 2 & 7 \\
\hline & 2016 & 5 & 3 & 1 & 2 & 7 & 8 & 6 & 4 \\
\hline & 2017 & 6 & 5 & 1 & 3 & 8 & 7 & 2 & 4 \\
\hline & 2018 & 6 & 7 & 1 & 8 & 3 & 4 & 2 & 5 \\
\hline \multirow{7}{*}{$\begin{array}{l}\text { The share of } \\
\text { material costs } \\
\text { in total costs, } \\
\text { percent }\end{array}$} & 2012 & 5 & 4 & 8 & 1 & 6 & 7 & 3 & 2 \\
\hline & 2013 & 4 & 5 & 8 & 3 & 6 & 1 & 7 & 2 \\
\hline & 2014 & 6 & 1 & 8 & 5 & 4 & 3 & 7 & 2 \\
\hline & 2015 & 7 & 2 & 8 & 1 & 6 & 5 & 4 & 3 \\
\hline & 2016 & 8 & 4 & 2 & 1 & 3 & 7 & 5 & 6 \\
\hline & 2017 & 8 & 4 & 7 & 5 & 2 & 3 & 6 & 1 \\
\hline & 2018 & 7 & 5 & 4 & 8 & 1 & 6 & 3 & 2 \\
\hline \multirow{7}{*}{$\begin{array}{l}\text { Payback of } \\
\text { materials, } \\
\text { rubles per ruble }\end{array}$} & 2012 & 5 & 4 & 6 & 2 & 1 & 7 & 3 & 8 \\
\hline & 2013 & 4 & 7 & 5 & 6 & 2 & 8 & 1 & 3 \\
\hline & 2014 & 4 & 3 & 8 & 1 & 6 & 2 & 7 & 5 \\
\hline & 2015 & 4 & 1 & 8 & 6 & 5 & 7 & 2 & 3 \\
\hline & 2016 & 3 & 1 & 5 & 6 & 7 & 8 & 2 & 4 \\
\hline & 2017 & 1 & 3 & 2 & 6 & 7 & 8 & 4 & 5 \\
\hline & 2018 & 6 & 5 & 4 & 8 & 1 & 7 & 3 & 2 \\
\hline \multirow{7}{*}{$\begin{array}{l}\text { Material } \\
\text { consumption, } \\
\text { rubles per ruble }\end{array}$} & 2012 & 5 & 4 & 6 & 2 & 1 & 7 & 3 & 8 \\
\hline & 2013 & 4 & 7 & 5 & 6 & 2 & 8 & 1 & 3 \\
\hline & 2014 & 4 & 3 & 8 & 1 & 6 & 2 & 7 & 5 \\
\hline & 2015 & 4 & 1 & 8 & 6 & 5 & 7 & 2 & 3 \\
\hline & 2016 & 3 & 1 & 5 & 6 & 7 & 8 & 2 & 4 \\
\hline & 2017 & 1 & 3 & 2 & 6 & 7 & 8 & 4 & 5 \\
\hline & 2018 & 6 & 5 & 4 & 8 & 1 & 7 & 3 & 2 \\
\hline \multirow{7}{*}{$\begin{array}{l}\text { Resource } \\
\text { compliance } \\
\text { ratio (for } \\
\text { material costs), } \\
\text { rubles per ruble }\end{array}$} & 2012 & 6 & 7 & 3 & 8 & 5 & 1 & 2 & 4 \\
\hline & 2013 & 6 & 7 & 3 & 8 & 5 & 1 & 2 & 4 \\
\hline & 2014 & 6 & 8 & 3 & 7 & 5 & 1 & 2 & 4 \\
\hline & 2015 & 7 & 6 & 3 & 8 & 5 & 1 & 2 & 4 \\
\hline & 2016 & 6 & 5 & 4 & 7 & 8 & 1 & 2 & 3 \\
\hline & 2017 & 7 & 5 & 2 & 6 & 8 & 1 & 4 & 3 \\
\hline & 2018 & 6 & 3 & 2 & 4 & 8 & 1 & 7 & 5 \\
\hline \multirow{5}{*}{$\begin{array}{l}\text { Sum of places } \\
\text { by indicators } \\
\text { for the period, } \\
\text { number }\end{array}$} & K1 & 32 & 34 & 26 & 29 & 33 & 49 & 16 & 33 \\
\hline & K2 & 45 & 25 & 45 & 24 & 28 & 32 & 35 & 18 \\
\hline & K3 & 27 & 24 & 38 & 35 & 29 & 47 & 22 & 30 \\
\hline & K4 & 27 & 24 & 38 & 35 & 29 & 47 & 22 & 30 \\
\hline & K5 & 44 & 41 & 20 & 48 & 44 & 7 & 21 & 27 \\
\hline \multirow{5}{*}{$\begin{array}{l}\text { Organization } \\
\text { rating by } \\
\text { indicators for } \\
\text { the period }\end{array}$} & K1 & 4 & 7 & 2 & 3 & 5 & 8 & 1 & 5 \\
\hline & К2 & 7 & 3 & 7 & 2 & 4 & 5 & 6 & 1 \\
\hline & K3 & 3 & 2 & 7 & 6 & 4 & 8 & 1 & 5 \\
\hline & K4 & 3 & 2 & 7 & 6 & 4 & 8 & 1 & 5 \\
\hline & K5 & 6 & 5 & 2 & 8 & 6 & 1 & 3 & 4 \\
\hline \multirow{7}{*}{$\begin{array}{l}\text { Sum of places } \\
\text { by years, } \\
\text { number }\end{array}$} & 2012 & 24 & 25 & 30 & 18 & 14 & 30 & 13 & 26 \\
\hline & 2013 & 22 & 32 & 29 & 26 & 17 & 25 & 12 & 17 \\
\hline & 2014 & 23 & 21 & 29 & 19 & 29 & 15 & 24 & 20 \\
\hline & 2015 & 27 & 11 & 33 & 24 & 25 & 28 & 12 & 20 \\
\hline & 2016 & 25 & 14 & 17 & 22 & 32 & 32 & 17 & 21 \\
\hline & 2017 & 23 & 20 & 14 & 26 & 32 & 27 & 20 & 18 \\
\hline & 2018 & 31 & 25 & 15 & 36 & 14 & 25 & 18 & 16 \\
\hline \multirow{7}{*}{$\begin{array}{l}\text { Organization } \\
\text { rating by years, } \\
\text { place }\end{array}$} & 2012 & 4 & 5 & 7 & 3 & 2 & 7 & 1 & 6 \\
\hline & 2013 & 4 & 8 & 7 & 6 & 2 & 5 & 1 & 2 \\
\hline & 2014 & 5 & 4 & 7 & 2 & 7 & 1 & 6 & 3 \\
\hline & 2015 & 6 & 1 & 8 & 4 & 5 & 7 & 2 & 3 \\
\hline & 2016 & 6 & 1 & 2 & 5 & 7 & 7 & 2 & 4 \\
\hline & 2017 & 5 & 3 & 1 & 6 & 8 & 7 & 3 & 2 \\
\hline & 2018 & 7 & 5 & 2 & 8 & 1 & 5 & 4 & 3 \\
\hline $\begin{array}{l}\text { The total amour } \\
\text { places in genera }\end{array}$ & $\begin{array}{l}\text { of } \\
\text { for }\end{array}$ & 17 & 14 & 16 & 17 & 16 & 18 & 11 & 13 \\
\hline $\begin{array}{l}\text { the period for a } \\
\text { key indicators }\end{array}$ & the & 5 & 8 & 7 & 1 & 3 & 2 & 6 & 8 \\
\hline $\begin{array}{l}\text { Integrated avera } \\
\text { rating for the pe }\end{array}$ & & 7 & 3 & 5 & 6 & 4 & 8 & 1 & 2 \\
\hline
\end{tabular}


The results of the ranking of key indicators of the organization C6 are interesting, which despite the first place in terms of $\mathrm{K} 5$, took the last place, which indicates the prevailing influence of other non-resource factors, including the labor and technical component of economic activity. A significant dispersion of the rating results among organizations (Fig. 1) indicates an insufficiently stable state of the raw material component. In addition, the rank of the values of the resource compliance ratio in 5 out of 8 organizations is two positions lower than the integral rating. On the other hand, the revealed variance of the ranks of other indicators is an indicator of the presence of underused opportunities to activate the raw material component of the resource potential.

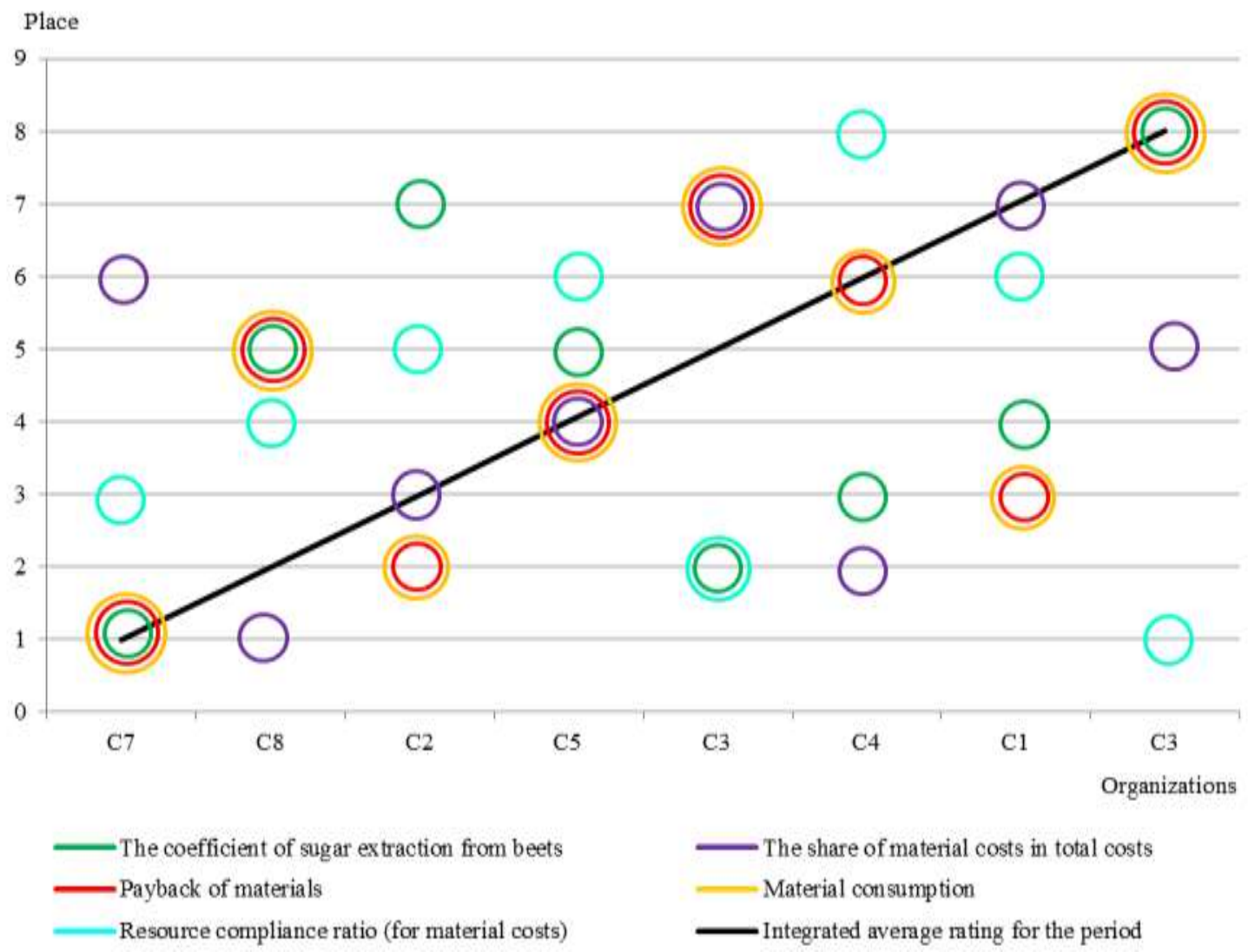

Fig. 1. Key indicators of the raw material component of economic activity, ranked by the value of the integrated rating for organizations $\mathrm{C} 1-\mathrm{C} 8$ of the Voronezh region on average for 2012-2018

\section{CONCLUSION}

The performed evaluation procedures of the developed methodology for rating the raw material component and tested using information on sugar production organizations for 20122018, gave reason to draw the following conclusions:

1) a significant range of variations in the level of key indicators selected for the rating assessment made it possible to recognize that the management decisions of the organizations under study in the field of the development of the raw material component of economic activity were not effective enough;

2) the suboptimal level of some key indicators reveals unused opportunities for activating the raw material component of economic activity;

3) organizations that have the highest daily sugar beet processing capacity have not been able to fully use this material and technical advantage over other sugar factories and provide a leading position in terms of the integral rating;
4) despite the profitable activities of the studied organizations, none of the organizations developed according to an absolutely optimistic scenario, which indicates some omissions in the use of the resource, including raw materials, potential and the need to improve individual tools used by the production and strategic management of organizations;

5) to increase the objectivity of the conclusions of the procedure for rating the components of economic activity, it is necessary to carry it out systematically, that is, in combination with the assessment of labor and technical components, and compare the conclusions with the production results of the economic activity of the organization.

\section{References}

[1] A.A. Kuzubov, "Criteria for evaluating an investment attractiveness of agricultural companies", Russ. J. of Agricult. and Socio-Econ. Sci., vol. 68 , no. $8,2017$.

[2] A.D. Sheremet, M.G. Garmash, "3.8. Integrated rating assessment of enterprise development sustainability", Audit and financial anal., vol. 3-4, pp. 152-157, 2017. 
[3] A.D. Sheremet, E.V. Lyubimtseva, "The use of analytical procedures to assess the sustainability and effectiveness of the company", Audit and financial anal., vol. 5, pp. 150-157, 2015.

[4] D. Shageev, T. Chuhonceva, "Universal rapid method of assessment and management decision-making of situational problems in the enterprise", Proc. of the Voronezh State Univer. of Engineer. Technol., vol. 81, no. 2, pp. 359-376. 2019.

[5] D.A. Endovitskii, N.P. Lyubushin, N.E. Babicheva, O.M. Kupryushina, "From assessment of organization's financial standing to integrated methodology for analysis of sustainable development", Dajdzhestfinansy, vol. 22, no. 2(242), pp. 123-143, 2017.

[6] G.V. Savitskaya, "Problematic aspects of calculating business performance indicators", J. of Manag. Stud., vol. 3, no. 3, pp. 1-28, 2017.

[7] G.V. Savitskaya, "Criteria and indicators of economic efficiency of a business", J. of Manag. Stud., vol. 3, no. 2, pp. 26-48, 2017.

[8] M.V. Melnik, "Evaluation of the methodology of accounting and control and analytical processes for the effective use of the capabilities of the digital economy", Econ. and Manag.: Probl., Solut., vol. 8, no. 3, pp. 11-16, 2019.

[9] N.S. Plaskova, "Development of the methodology of economic analysis", Account. Anal. Audit, vol. 1, pp. 50-57, 2016.
[10] O. Toluwa, O. Power, "Fair Value Accounting: A Conceptual Approach", Int. J. Of Acad. Res. In Busin. And Soc. Sci., vol. 9, pp. 683-696, 2019.

[11] R. Nuzhdin, E. Endovitskaya, "Assessment of the raw materials and labor components of sugar beet production: methodological justification", Sugar, vol. 11, pp. 50-54, 2018.

[12] R.R. Chugumbaev, N.N. Chugumbaeva, "The historical role of economic analysis in the development of business of modern companies", Econ. anal.: theory and pract., vol. 48, no. 447, pp. 25-36, 2015 .

[13] S.V. Ovchinnikova, "Improving the methodology for calculating the performance indicators of a business unit", Econ. and Entrepreneurship, vol. 11-1, pp. 846-849, 2015.

[14] V.I. Barilenko, "Expanding tasks and opportunities of complex economic analysis", Audit, vol. 11, pp. 7-9, 2019.

[15] V.V. Syroizhko, "Economic modeling and rating assessment of the activities of cooperative organizations of the Voronezh region", Audit and financial anal., vol. 6, pp. 170-173, 2013.

[16] V.V. Kovalev, V.V. Kovalev, "Accounting and Analysis: Current Challenges and Trends", pp. 245-253, 2016 [5th Int. Conf. on Account., Auditing. and Taxat. (ICAAT 2016)]. Atlantis Press.

[17] Y.P. Demidov, "Theory and practice of modern rating: critical notes", Econ. anal.: theory and pract., vol. 8, no. 311, pp. 14-19, 2013. 